\title{
Microbial Biomass and Phosphomonoesterase Activity of the Willow (Salix sp.) Rhizosphere in a Heavy Metal Polluted Soil
}

\author{
${ }^{1}$ T. SZILI-KOVÁCS, ${ }^{1}$ G. MÁTHÉ-GÁSPÁR, ${ }^{2}$ P. MÁTHÉ and ${ }^{1}$ A. ANTON \\ ${ }^{1}$ Research Institute for Soil Science and Agricultural Chemistry (RISSAC) of the \\ Hungarian Academy of Sciences, Budapest and \\ ${ }^{2}$ Károly Róbert College, Gyöngyös (Hungary)
}

\section{Introduction}

Biological and biochemical parameters, such as microbial biomass and enzyme activities are considered as indicators of soil quality (BROOKES, 1995; SZILIKovÁCS et al., 1998; ABDORHIM et al., 2004; SIMON \& BIRÓ, 2005; GIL-SOTRES et al., 2005). It has become evident that microbial biomass decreases due to metal contamination in soils (FILIP, 1998).

KANDELER et al. (1996) studied 16 different soil microbial parameters in soils treated with heavy metals. The enzymes related to $\mathrm{C}$ decomposition were less influenced by metal treatments, while arylsulphatase and phosphatase activities were among the most sensitive microbial properties.

Phosphatase activity responded sensitively to metal contamination according to several studies (MÁTHÉ, 1978; MÁTHÉ \& KOVÁCS, 1980; ANTON et al., 1994; MÁTHÉ-GÁSPÁR et al., 2005). Different phosphatase reactions affecting heavy metals are determined by the forms and concentration of the metals and soil properties (e.g. pH) (TYLER, 1974; BROOKES, 1995; OsZTOICS et al., 2003). KNIGHT et al. (1997) added $\mathrm{Cu}, \mathrm{Cd}$ and $\mathrm{Zn}$ to the soil in loads around the current UK limit values. The $\mathrm{Cu}$ treatments decreased the microbial biomass $\mathrm{C}$, while $\mathrm{Cu}$ and $\mathrm{Zn}$ reduced the metabolic potential of the soil microbial community. Decreased microbial biomass $\mathrm{C}$ has been observed in soils amended with sewage sludge enriched with $\mathrm{Cu}, \mathrm{Ni}, \mathrm{Zn}$ and $\mathrm{Cd}$ metals by chloroform fumigation incubation and microscopic investigations, as well (BROOKES et al., 1986).

FLIESSBACH et al. (1994) investigated the effect of metal enriched $(\mathrm{Cr}, \mathrm{Cu}, \mathrm{Cd}$, $\mathrm{Pb}, \mathrm{Hg}, \mathrm{Ni}, \mathrm{Zn}$ ) sewage sludge on soil microbial activity. There was a decline in microbial biomass $\mathrm{C}$ and the ratio of biomass $\mathrm{C} /$ soil organic $\mathrm{C}$, while biomass specific respiration (especially the fungal respiration) increased in greater extent due to the treatments. AOYAMA and NAGUMO (1996) found that the ratio of biomass C/soil organic $\mathrm{C}$ and dehydrogenase activity decreased after adding the Bordeaux mixture to the soil. MORENO et al. (1999) examined the effect of cadmium contaminated

Correspondence to: TIBOR SZILI-KOVÁCS, Research Institute for Soil Science and Agricultural Chemistry of the Hungarian Academy of Sciences, H-1022 Budapest, Herman Ottó út 15. Hungary.E-mail: szili_k@rissac.hu 
sewage sludge compost on the microbial biomass and activity of a soil having low fertility. Different fractions of organic carbon increased in all treatments, but, parallel with the decrease in microbial biomass $\mathrm{C}$ in the soil treated with compost with high $\mathrm{Cd}$ content, there was an increase in the metabolic quotient (biomass specific respiration).

The majority of investigations are based on the soil's metal enrichment in laboratory and very few attempts have been made for studies under field conditions. The examination of this latter situation is hard to manage because of the spatial variability of sites (DOMBOS \& SZALKAI, 2004) and pollutants (MÁTHÉ-GÁSPÁR et al., 2004), and it is also difficult to find an appropriate uncontaminated control site (KÁDÁR \& NÉMETH, 2003; D. TÓTH et al., 2005). In their investigation of experimentally metal-polluted field plots seven years after metal loading SzILI-KovÁCS et al. (1999) found that all soils contaminated with $\mathrm{Cu}, \mathrm{Ni}, \mathrm{Zn}$ and $\mathrm{Cd}$ had lower microbial biomass C than the control. DUMONTET \& MATHUR (1989) stated that the microbial biomass $\mathrm{C}$ and biomass $\mathrm{C} /$ soil organic $\mathrm{C}$ ratio decreased towards a copper smelter where $\mathrm{Cu}, \mathrm{Zn}, \mathrm{Cd}$ and $\mathrm{Pb}$ metals occurred in enhanced concentrations in soil. TAKÁCS et al. (2005) - analyzing mycorrhizal development and survival in a metal polluted industrial soil - established that metal-adapted AM fungi helped the survival of the host plant under metal stress conditions.

The present paper's objective was to follow the changes in soil microbial biomass $\mathrm{C}$ and phosphomonoesterase activity, as if they were influenced by heavy metal pollution under field conditions.

\section{Materials and Methods}

Experimental site. - The experimental site is located on the bank of the Toka River near Gyöngyösoroszi (North-East Hungary) close to an abandoned $\mathrm{Pb} / \mathrm{Zn}$ mine. The soil type is Fluvisol. The climate of the region is temperate with continental features. The vegetation is heterogeneous, including natural and weedy elements as well.

Treatments. - A phytoremediation experiment was set up in 2003 by planting willow trees (Salix sp.) in rows along the polluted and unpolluted sites. The polluted area is located in an approximately $10 \mathrm{~m}$ wide strip along the river. The site farther away from the river was considered as unpolluted, according to the soil chemical data.

Sampling. - Rhizosphere soil samples were taken from the 0-20 cm depth at six-six unpolluted (UP) and polluted (P) points around the planted willows (Salix sp.) on 6 October,2004. The moist samples were sieved ( $2 \mathrm{~mm}$ mesh) and stored at $4{ }^{\circ} \mathrm{C}$ until the analyses were performed.

Soil chemical analyses. - Basic soil characteristics, such as humus content, $\mathrm{pH}$, $\mathrm{CaCO}_{3}, \mathrm{~K}_{\mathrm{A}}$ (plasticity according to Arany), salt and moisture content were measured. The total and "available" content of 22 elements extracted with aqua regia 
$\left(\mathrm{HCl} / \mathrm{HNO}_{3}\right)$ and $\mathrm{LE}-$ method $\left(\mathrm{NH}_{4}\right.$-acetate-EDTA) were analyzed by ICP spectrometry.

Microbial biomass $C$ response. - The microbial biomass $\mathrm{C}$ of the rhizosphere soil samples under willow was estimated by chloroform fumigation extraction (VANCE et al., 1987; SzILI-KOVÁCS \& TÖRÖK, 2005). $15 \mathrm{~g}$ soil was fumigated by chloroform in a desiccator for 2 min, then left overnight. After chloroform removal by repeated vacuum, fumigated and unfumigated samples were extracted by $0.1 \mathrm{M}$ $\mathrm{K}_{2} \mathrm{SO}_{4}$ after shaking, filtered through a Schleicher \& Schuell 589/3 (blue ribbon) paper and the organic carbon was measured by a Shimadzu TOC analyzer in NPOC mode (non-purgeable organic $\mathrm{C}$ ). Biomass $\mathrm{C}$ was calculated as the difference in extracted organic $\mathrm{C}$ between the fumigated and unfumigated samples multiplied by a conversion factor $\left(\mathrm{k}_{\mathrm{EC}}=2.63\right)$.

Phosphatase activity. - The acid phosphatase activity of soil was measured at sampling. Phosphatase activities were determined according to TABATABAI \& BREMNER (1969). One $\mathrm{g}$ of moist fresh soil was incubated in $4 \mathrm{~mL}$ modified universal buffer ( $\mathrm{pH} 5.5$ for acid phosphatase) and $1 \mathrm{~mL}$ p-nitrophenyl phosphate (15 $\mathrm{mM})$ for $1 \mathrm{~h}$ at $37^{\circ} \mathrm{C}$. After incubation, $1 \mathrm{~mL} \mathrm{CaCl}_{2}(0.5 \mathrm{M})$ and $4 \mathrm{~mL} \mathrm{NaOH}(0.5$ $M$ ) were added to stop the reaction and to raise the $\mathrm{pH}$. The nitrophenol concentration was determined photometrically at $410 \mathrm{~nm}$.

Data analysis. - Chemical data of the soil samples were analyzed by principal component analysis (PODANI, 2001). The biomass $\mathrm{C}$ and acid phosphomonoesterase activity values between the polluted and unpolluted sites were compared by twosamples t-test. Linear regression was calculated between the measured variables.

\section{Results and Discussion}

\section{Heavy metal contamination}

A significant metal accumulation occurred in all samples throughout the polluted site (Table 1) especially in the case of $\mathrm{As}, \mathrm{Cd}, \mathrm{Cu}, \mathrm{Pb}$ and $\mathrm{Zn}$. Repeated flooding may deposit sediments containing metals in high concentrations.

The total organic $\mathrm{C}$ (or humus content) and $\mathrm{pH}$ did not differ significantly in the polluted and unpolluted sites (Table 1$)$. The plasticity index $\left(\mathrm{K}_{\mathrm{A}}\right)$ was somewhat higher in the uncontaminated soils, which indicates higher clay content.

Polluted and unpolluted samples were sharply differentiated by their chemical properties according to the principal component analysis (Fig. 1). The unpolluted samples were in a much closer group. The higher dispersion of polluted samples was observable, which was caused by the different level of metal accumulation. The largest distance was between the most (P2) and the least (P3) polluted samples within the contaminated area. 
Table 1

Main properties and metal accumulation in soils around planted willows $(0-20 \mathrm{~cm})$ at the unpolluted (UP) and polluted (P) sites of the phytoremediation experiment along the Toka River

\begin{tabular}{|c|c|c|c|c|c|c|c|c|c|}
\hline \multirow{2}{*}{$\begin{array}{c}\text { Soil } \\
\text { sample }\end{array}$} & \multirow{2}{*}{$\begin{array}{c}\text { Humus } \\
\%\end{array}$} & \multirow{2}{*}{$\begin{array}{c}\mathrm{pH} \\
\mathrm{KCl}\end{array}$} & \multirow{2}{*}{$\begin{array}{c}\mathrm{CaCO}_{3} \\
\%\end{array}$} & \multirow{2}{*}{$\mathrm{K}_{\mathrm{A}}$} & As & $\mathrm{Cd}$ & $\mathrm{Cu}$ & $\mathrm{Pb}$ & $\mathrm{Zn}$ \\
\hline & & & & & \multicolumn{5}{|c|}{$\mathrm{mg} \cdot \mathrm{kg}^{-1}$ soil } \\
\hline \multicolumn{10}{|c|}{ Unpolluted soil } \\
\hline UP1 & 2.51 & 6.86 & $0.57^{1}$ & 51 & 21.3 & 0.360 & 62.3 & 35 & 141 \\
\hline UP2 & 4.03 & 6.59 & 0.53 & 51 & 23.1 & 0.618 & 84.5 & 47 & 211 \\
\hline UP3 & 4.12 & 6.50 & 0 & 49 & 25.4 & 0.932 & 100 & 65 & 274 \\
\hline UP4 & 3.01 & 6.59 & 0 & 46 & 24.4 & 1.05 & 90.4 & 64 & 285 \\
\hline UP5 & 3.31 & 6.55 & 0 & 47 & 22.6 & 0.575 & 87.5 & 47 & 199 \\
\hline UP6 & 3.58 & 6.51 & 0 & 47 & 21.6 & 0.698 & 105 & 56 & 221 \\
\hline \multicolumn{10}{|c|}{ Polluted soil } \\
\hline P1 & 3.51 & 6.47 & 0 & 44 & 216 & 19.7 & 325 & 1409 & 3181 \\
\hline P2 & 2.00 & 6.86 & 0 & 42 & 341 & 28.8 & 493 & 2827 & 4417 \\
\hline P3 & 3.08 & 6.32 & 0 & 44 & 147 & 11.9 & 197 & 724 & 2190 \\
\hline P4 & 3.62 & 6.53 & 0 & 48 & 190 & 18.9 & 298 & 1183 & 3185 \\
\hline P5 & 3.46 & 6.46 & 0 & 46 & 204 & 16.9 & 315 & 1620 & 2873 \\
\hline P6 & 2.56 & 6.28 & 0 & 44 & 240 & 15.4 & 364 & 1974 & 2650 \\
\hline
\end{tabular}

$\mathrm{K}_{\mathrm{A}}=$ plasticity according to Arany

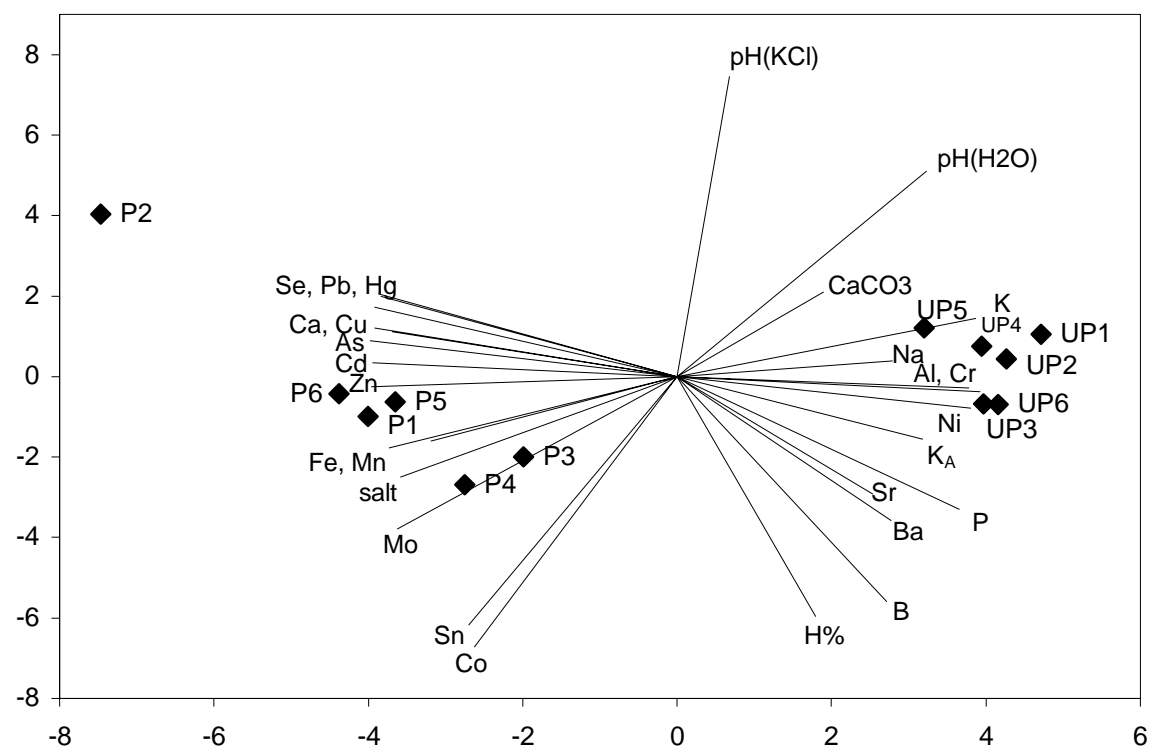

Fig. 1

PCA biplot of the polluted (P1-P6) and unpolluted (UP1-UP6) soil samples according to the chemical data. The first component (x, horizontal axis) is responsible for $70 \%$ of the total variance (Phytoremediation experiment with planted willow along the Toka River) 


\section{Microbial biomass response}

Microbial biomass $\mathrm{C}$ was significantly higher in unpolluted soils in comparison to the polluted ones (Fig. 2). The standard errors were higher in unpolluted soils, which is probably attributable to the heterogeneous nature of the sample having microsites with various microbial activities. The average soil microbial biomass $\mathrm{C}$ was 186 and $71 \mathrm{mg} \cdot \mathrm{kg}^{-1}$ for unpolluted and polluted soils, respectively.

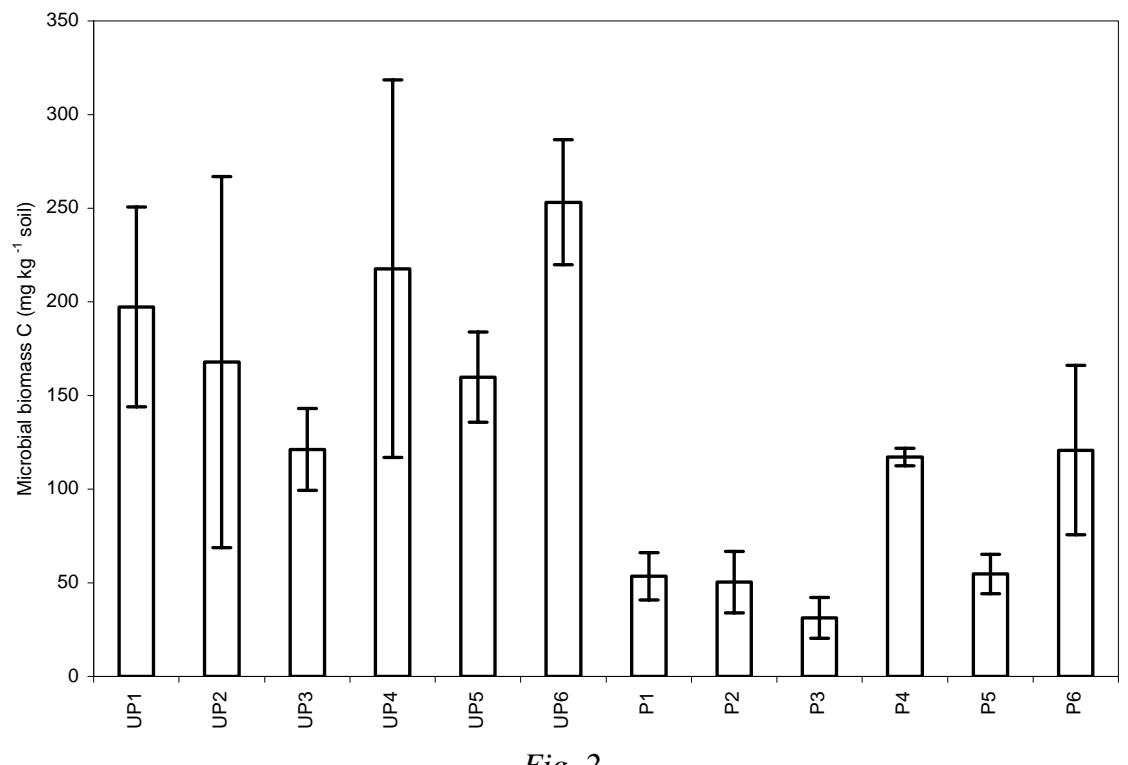

Fig. 2

Microbial biomass $\mathrm{C}$ of the investigated unpolluted (UP1-UP6) and polluted (P1-P6) soil samples originating from a phytoremediation experiment with planted willow along the Toka River. Data are means of 3 replicates indicating standard deviation

The three possible explanations for the microbial biomass depletion in contaminated soils are as follows:

1. The heavy metals accumulated in the soil alone could restrict the microbes as a toxic effect.

2. The metal induced stress probably increases the metabolic activity, resulting in a less efficient utilization of resources.

3. The metals might cause a decreased plant root activity, as a consequence of which the energy source for microbial growth is much lower.

CHANDER \& BROOKES (1991) using ${ }^{14} \mathrm{C}$-technique have concluded that these two latter mechanisms - reduced $\mathrm{C}$ inputs from plants to the soil and decreased efficiency of conversion of this $\mathrm{C}$ into new biomass $\mathrm{C}$ - operate in causing smaller biomasses in metal-contaminated soils. FLIESSBACH et al. (1994) and BARDGETT et al. (1994) stated that specific respiration activity (microbial respiration per unit 
biomass) was higher in metal contaminated than in uncontaminated soils, suggesting a less efficient substrate utilization in soils contaminated with metals.

\section{Phosphomonoesterase activity}

The phosphomonoesterase activity of unpolluted (UP) soil samples ranged between 0.78 and $0.97 \mu \mathrm{mol} \mathrm{pNP} \cdot \mathrm{g}^{-1}$ dry soil $\cdot \mathrm{h}^{-1}$, while due to pollution the acid phosphomonoesterase activity of the soil increased significantly $(0.88$ and $1.58 \mu \mathrm{mol}$ pNP. $\mathrm{g}^{-1}$ dry soil $\cdot \mathrm{h}^{-1}$ ) (Table 2). Soil moisture content was significantly higher, but the LE-soluble phosphorus content was significantly lower in polluted soil samples collected near to the bank of the Toka River than in the case of unpolluted soil (Table 2).

Phosphatases play an essential role in the cycling and availability of soil phosphorus. These enzymes occur either exocellularly or within the living cell, their sources are the soil microbial community as well as plant roots and residues.

\section{Table 2}

"Total" and LE-soluble phosphorus content, water content and acid phosphatase activity of unpolluted (UP) and polluted (P) soil samples originating from a phytoremediation experiment with planted willow along the Toka River

\begin{tabular}{|c|c|c|c|c|}
\hline \multirow{2}{*}{$\begin{array}{c}\text { Soil } \\
\text { samples }\end{array}$} & $\begin{array}{l}\text { Total P } \\
\text { content }\end{array}$ & $\begin{array}{c}\text { LE-P } \\
\text { content }\end{array}$ & \multirow{2}{*}{$\begin{array}{c}\text { Soil water } \\
\text { content } \\
\%\end{array}$} & \multirow{2}{*}{$\begin{array}{c}\text { Acid phosphatase } \\
\text { activity } \\
\mu \mathrm{mol} \mathrm{pNP} \cdot \mathrm{g}^{-1} \text { dry soil } \cdot \mathrm{h}^{-1}\end{array}$} \\
\hline & \multicolumn{2}{|c|}{$\mathrm{mg} \cdot \mathrm{kg}^{-1}$ dry soil } & & \\
\hline \multicolumn{5}{|c|}{ Unpolluted soil } \\
\hline UP1 & 1106 & 638 & 19.54 & $0.7805 \pm 0.0246$ \\
\hline UP2 & 1162 & 784 & 18.89 & $0.9692 \pm 0.0263$ \\
\hline UP3 & 1245 & 830 & 18.89 & $0.9619 \pm 0.0319$ \\
\hline UP4 & 1083 & 568 & 17.49 & $0.7774 \pm 0.0175$ \\
\hline UP5 & 1005 & 559 & 19.17 & $0.7792 \pm 0.0154$ \\
\hline UP6 & 1071 & 540 & 18.42 & $0.8207 \pm 0.0288$ \\
\hline Mean & $1112^{a}$ & $653^{a}$ & $18.74^{a}$ & $0.8482^{a}$ \\
\hline \multicolumn{5}{|c|}{ Polluted soil } \\
\hline P1 & 838 & 74,5 & 22.05 & $1.4550 \pm 0.0229$ \\
\hline $\mathrm{P} 2$ & 481 & 15,9 & 19.14 & $0.8776 \pm 0.0103$ \\
\hline P3 & 847 & 123 & 17.41 & $1.1203 \pm 0.0482$ \\
\hline P4 & 998 & 138 & 22.59 & $1.5853 \pm 0.0776$ \\
\hline P5 & 815 & 56,2 & 22.62 & $1.7210 \pm 0.0477$ \\
\hline P6 & 720 & 20,0 & 20.15 & $1.1858 \pm 0.0173$ \\
\hline Mean & $783^{a}$ & $71^{b}$ & $20.66^{b}$ & $1.3242^{b}$ \\
\hline
\end{tabular}

Remarks: Total P: extracted with $\mathrm{HCl} / \mathrm{HNO}_{3}$; LE-soluble P: $\mathrm{NH}_{4}$-acetate-EDTA, LakenenErviö method. Different letters in the upper index of the same column show significant difference $(\mathrm{p}<0.05)$ 
Changes in phosphatase activity affect the functioning of living organisms and soil properties. Soil contamination by heavy metals generally inhibits many organisms and enzymes, but soil characteristics - mainly organic carbon, clay content and $\mathrm{pH}$ - can modify them significantly (TYLER, 1974; MÁTHÉ, 1978; MÁTHÉ \& KOVÁCS, 1980; ANTON et al., 1994; TAKÁCS \& VÖRÖS, 2003; SzILI-KOVÁCS, 2004; URI et al., 2005). Results underline the importance of heavy metals and nutrient elements, primarily that of phosphate concentration (TYLER, 1974; MÁTHÉ, 1978; OsZTOICs et al., 2004; BIRÓ et al., 2005).

The phosphatase production of living organisms was stimulated by the higher moisture content and slightly lower total phosphorus content, and the significantly lower LE-soluble phosphorus content of the polluted soil samples. A positive correlation was established between soil water content and phosphatase activity $(\mathrm{r}=$ $+0.85, \mathrm{p}<0.05)$. On the other hand, the correlation between the LE-P content and phosphatase activity was negative $(\mathrm{r}=-0.69, \mathrm{p}<0.05)$. The low available phosphorus content, resulting from the high heavy metal $(\mathrm{Pb}, \mathrm{Zn})$ loading, had the most stimulating effect.

\section{Conclusions}

Soil contamination by heavy metals in the course of flooding resulted in a significant decrease in microbial biomass and increase in acid phosphatase activity under the willow (Salix sp.) plantation. Both measured biological parameters indicated soil pollution, but the changes were adverse: while biomass decreased, phosphatase activity increased. No correlation was found between microbial biomass and phosphatase activity, which indicates the different account of ecological factors that determine measured biological properties.

\section{Summary}

The applicability of the chloroform fumigation extraction method was tested for detecting soil microbial biomass and p-nitrophenyl phosphate (pNP) for acid phosphatase activity to study their response to heavy metal pollution in the rhizosphere soil of planted willow (Salix sp.).

The experimental site was located in the Toka River Valley (North-East Hungary) along the riverbank that had been severely polluted by flooding. The river had transported heavy metal and arsenic ions from several heaps deposited imprudently near a historic lead and zinc mining site. A phytoremediation experiment was set up by planting willow trees with the aim of extracting toxic elements from the soil. A strong significant difference between the control and the metal-contaminated rhizosphere soils resulted much lower microbial biomass values in the polluted soils, which suggests disturbance in the organic matter transformation dynamics.

A significant increase in acid phosphomonoesterase activity was determined in the soil due to the pollution. The phosphatase enzyme production of living organ- 
isms may be stimulated by the measured higher moisture content and significantly lower LE-soluble phosphorus content of the polluted soil samples. The correlation established between soil water content and phosphatase activity was positive $(r=$ $+0.85)$, while that between LE-P content and phosphatase activity was negative ( $\mathrm{r}=$ -0.69). The most important stimulating effect was attributable to the lower available phosphorus content, resulting from the heavy metal $(\mathrm{Pb}, \mathrm{Zn})$ content of polluted soil.

Both measured biological parameters therefore were suitable for indicating soil pollution, but the change was adverse, the biomass decreased, while phosphatase activity increased. Microbial biomass and phosphatase activity were not correlated, indicating the different account of ecological factors that alter the biological properties of a soil.

The present work was supported financially by the GVOP Program (Projects AKF 0257 and AKF 0261) and the Hungarian National Scientific Research Fund (OTKA) under grants T 042778 and T 038280.

Key words: heavy metal, microbial biomass, phosphatase activity, remediation

\section{References}

ABDORHIM, H. et al., 2004. Effect of sewage sludge doses on some microbial and biochemical parameters of a plant (Triticum vulgare L.)-soil system. (In Hungarian) Agrokémia és Talajtan. 53. 413-432.

ANTON, A. et al., 1994. Effect of environmental factors and Mn, Zn, Cu compounds on the phosphomonoesterase activity in soil. Acta Biologica Hungarica. 45. 39-50.

Aoyama, A. U. \& NAGUMO, T., 1996. Factors affecting microbial biomass and dehydrogenase activity in apple orchard soils with heavy metal accumulation. Soil Science and Plant Nutrition. 42. 821-813.

BARDGETT, R. D. et al., 1994. Impact of pasture contamination by copper, chromium and arsenic timber preservatives on soil microbial properties and nematodes. Biology and Fertility of Soils. 18. 71-79.

BIRÓ, B. et al., 2005. Mycorrhizal functioning as part of the survival mechanisms of barley (Hordeum vulgare L.) at long-term heavy metal stress. Acta Biologica Szegediensis. 49. 65-67.

BROOKES, P. C., 1995. The use of microbial parameters in monitoring soil pollution by heavy metals. Biology and Fertility of Soils. 19. 269-279.

BROOKES, P. C. et al., 1986. Soil microbial biomass estimates in soils contaminated with metals. Soil Biology and Biochemistry. 18. 383-388.

Chander, K. \& BRookes, P. C., 1991. Plant inputs of carbon to metal-contaminated soil and effects on the soil microbial biomass. Soil Biology and Biochemistry. 23. 1169-1177. 
D. Tóth, M. et al., 2005. Cadmium, copper, nickel and zinc content of ragweed (Ambrosia elatior L.) on ruderal sites. (In Hungarian) Agrokémia és Talajtan. 54. 403416.

Dombos, M. \& SzalkaI, T., 2004. Indication models and their applications in soil ecology. (In Hungarian) Agrokémia és Talajtan. 53. 181-194.

DuMONTET, S. \& MATHUR, S. P., 1989. Evaluation of respiration-based methods for measuring microbial biomass in metal-contaminated acidic mineral and organic soils. Soil Biology and Biochemistry. 21. 431-436.

FILIP, Z., 1998. An internationally based approach to assess soil quality by biological methods. Proc. $16^{\text {th }}$ World Congress of Soil Science, Montpellier, Symp. 37. CDROM.

Fliessbach, A., Martens, R. \& Reber, H. H., 1994. Soil microbial biomass and microbial activity in soils treated with heavy metal contaminated sewage-sludge. Soil Biology and Biochemistry. 26. 1201-1205.

GIL-SOTRES, F. et al., 2005. Different approaches to evaluating soil quality using biochemical properties. Soil Biology and Biochemistry. 37. 877-887.

KÁDÁR, I. \& NÉMETH, T., 2003. Studies on the leaching of microelement pollutants in a long-term field experiment. (In Hungarian) Agrokémia és Talajtan. 52. 315-330.

KANDELER, A. U., KAMPICHLER, E. \& HORAK, O., 1996. Influence of heavy metals on the functional diversity of soil microbial communities. Biology and Fertility of Soils. 23. 299-306.

KNight, A. U., McGrath, S. P. \& ChAudri, A. M., 1997. Biomass carbon measurement and substrate utilization pattern of microbial populations from soils amended with cadmium, copper or zinc. Applied and Environmental Microbiology. 63. 3943.

MÁTHÉ, P., 1978. Effect of Manganese and Zinc on Phosphatase Activity of Soils. (In Hungarian) Thesis. University of Agricultural Sciences. Gödöllö.

MÁthé, P. \& KovÁCs, G. J., 1980. Effect of Mn and Zn on the phosphatase activity of soils. (In Hungarian) Agrokémia és Talajtan. 29. 441-446.

MÁTHÉ-GÁsPÁR, G., MÁTHÉ, P. \& ANTON, A., 2005. Change of acid phosphatase activity in a heavy metal polluted soil. Acta Microbiol. Immunol. Hung. 52. 94-95.

MÁTHÉ-GÁSPÁR, G. et al., 2004. After-effect of cadmium load on the soil and plants on a brown forest soil. (In Hungarian) Agrokémia és Talajtan. 53. 143-154.

Moreno, J. L., HernándeZ, T. \& GARCIA, C., 1999. Effects of a cadmium contaminated sewage sludge compost on dynamics of organic matter and microbial activity in an arid soil. Biology and Fertility of Soils. 28. 230-237.

Osztoics, E., CsATHÓ, P. \& RADIMSZKY, L., 2004. Investigations on the effect of Algerian rock phosphate and superphosphate. IV. Effect of soil properties, phosphorus fertilizers and phosphorus rates on the $\mathrm{Mn}, \mathrm{Ni}, \mathrm{Al}, \mathrm{Co}$ and Mo concentrations of red clover in a pot experiment. (In Hungarian) Agrokémia és Talajtan. 53. 125142.

OszTOICS, E. et al., 2003. Investigations on the effect of Algerian rock phosphate and superphosphate. III. Effect of soil properties, form and rate of phosphorus on the $\mathrm{Cd}, \mathrm{Cr}$ and $\mathrm{Sr}$ concentrations of red clover in a pot experiment. (In Hungarian) Agrokémia és Talajtan. 52. 363-382

PoDANI, J., 2001. Syn-tax 2000 Computer Program for Data Analysis in Ecology and Systematics. Scientia Publishing. Budapest. 
SIMON, L. \& BIRÓ, B., 2005. Role of amendments, red fescue and Zn-tolerant mycorrhizal fungi in the remediation of a metal contaminated mine spoil from Gyöngyösoroszi. (In Hungarian) Agrokémia és Talajtan. 54. 163-176.

SzILI-KovÁCS, T. 2004. Substrate induced respiration in soils - A review (In Hungarian) Agrokémia és Talajtan. 53. 195-214.

SzILI-KOVÁCS, T. \& TÖRÖK, K., 2005. Effect of carbon addition on the soil microbial activity and biomass on abandoned sandy fields. (In Hungarian) Agrokémia és Talajtan. 54. 149-162.

Szili-KovÁCs, T., Anton, A. \& Gulyás, F., 1999. Effect of Cd, Ni, and $\mathrm{Cu}$ on some microbial properties of a calcareous chernozem soil. In: Proc. $2^{\text {nd }}$ Symp. on "Pathways and Consequences of the Dissemination of Pollutants in the Biosphere", Prague. (Ed.: KuBÁT, J.) 88-102.

SzILI-KovÁCs, T. et al., 1998. Soil microbial biomass-C as a possible indicator of soil pollution. Agrokémia és Talajtan. 47. 253-264.

TABATABAI, M. A. \& BREMNER, M., 1969. Use of p-nitrophenyl phosphate for assay of phosphatase activity. Soil Biology and Biochemistry. 1.301-307.

TAKÁCS, T. \& VÖRÖS, I., 2003. Effect of metal non-adapted arbuscular mycorrhizal fungi on $\mathrm{Cd}$, Ni and Zn uptake by ryegrass. Acta Agronomica Hungarica. 51. 347354.

TAKÁCS, T., RADIMSZKY, L. \& NÉMETH, T., 2005. The arbuscular mycorrhizal status of poplar clones selected for phytoremediation of soils contaminated with heavy metals. Z. Naturforsch. 60. 357-361.

TYLER, G., 1974. Heavy metal pollution and soil enzymatic activity. Plant and Soil. 41. 303-311.

URI, Zs. et al., 2005. Effect of variously pre-treated municipal sewage sludge on the microbe composition and enzyme activity of the soil. (In Hungarian) Agrokémia és Talajtan. 54. 439-450.

VAnce, E. D., BRookes, P. C. \& Jenkinson, D. S., 1987. An extraction method for measuring soil microbial biomass-C. Soil Biology and Biochemistry. 19. 703-707. 